\title{
Quality of Faculty Life and Lifelong Learning Tendencies of University Students
}

\author{
Osman Ferda Beytekin ${ }^{1} \&$ Ayşegül $\operatorname{Kad}^{1}$ \\ ${ }^{1}$ Faculty of Education, Ege University, Izmir, Turkey \\ Correspondence: Osman Ferda Beytekin, Faculty of Education, Ege University, Izmir, Turkey. Tel: \\ 90-532-723-5514. E-mail: ferda.beytekin@ege.edu.tr
}

Received: August 6, 2014

Accepted: August 27, $2014 \quad$ Online Published: September 20, 2014

doi:10.5539/hes.v4n5p28

URL: http://dx.doi.org/10.5539/hes.v4n5p28

\begin{abstract}
The purpose of this study is to examine the university students' opinions about quality of faculty life and their lifelong learning tendencies. Research was conducted with 375 university students. According to the findings: the quality of faculty life of students differ according to gender. Male students have lower quality of faculty life than female students and male students have higher lifelong learning tendency than female students. Lifelong learning tendency of students differ according to classroom level variable. Second grade students have higher lifelong learning tendency than fourth grade students. Third grade students have lower quality of faculty life of the other students. Lifelong learning tendency of students differ according to field of study. Educational sciences students have lower lifelong learning tendency than computer and instructional technology students. Computer and instructional technology students have lower quality of faculty life than educational sciences students and fine arts students. Educational sciences students have higher quality of faculty life than elementary education students. The results reveal that the opinions of university students about quality of faculty life is a significant predictor of their opinions about life long learning tendencies. Students' opinions to fulfill their goals are seen vital as being one of the most important factor within the context of university management. It is important that to search and find out the quality of faculty life and life learning tendecies of university students help to increase the level of quality of faculty life and so generating education policies according to these results. Therefore analysing the opinions of university students on quality of faculty life and lifelong learning tendencies is expected to develop new faculty management strategies and provide important benefits to researchers and implementors. Besides that lifelong learning tendencies can be affected by other variables and they may be investigated in the next researches.
\end{abstract}

Keywords: lifelong learning tendency, quality of faculty life, university students

\section{Introduction}

If we want to acquire information about the quality of education in our era, it is useful to analyse the humane and cultural elements (Wilson, 1980). Quality means; feature that helps to seperate a thing from the others and it is important in life of an individual. Life quality can be generally described as happiness of an individual. When we think about quality of the school life; positive and negative feelings, experiences and combination of the situations are come to mind. These phenomenons in school life can be the quality of students' and teachers' school life (Leonard, 2002; Schofield \& Bourke, 1997; Waugh \& Hyde, 1993).

Quality of school life is divided into three dimension by the researchers: satisfaction with school, commitment to class tasks and reactions to teacher. Satisfaction with school consists of students' reaction to school and is said that students who take part in school activities have higher academic success. Even more, students who like school pay attention to help each other (Çokluk Bökeoğlu \& Yılmaz, 2007). "Commitment to class tasks" is related to tasks of students in the classroom. If homework and projects sound interesting for students, the student will be eager to learn. "Reactions to teacher" deals with the interaction between student, teacher and student assessment. Student-teacher relationship is an important element in themes like students' participation during the organization of education objectives, students' comprehension to school practices, students' dependent and independent behaviours and their attitude towards the in- and out-school authorities (Schmidt, 1992; Schmidt \& Lunenberg, 1989).

Dimensions of quality of faculty life is similar to dimension of quality of school life. The dimensions that take 
place in studies on quality of school life like "satisfaction with school", "commitment to class tasks", "reactions to teacher" are generated as subdimensions like "class atmosphere and satisfaction with relations to students", "satisfaction with instructors" and "satisfaction with faculty" (Yılmaz \& Çokluk Bökeoğlu, 2006).

Life-long learning is a concept which provides socio-cultural and professional development for individuals. According to Erdamar (2011); lifelong learning, individual's self-recognition and recognition of the world, to learn new knowledge and skills, to create something, to be aware of new beauty in the world. According to Şişman (2012), continuous increase of the information to be learned, the concept of lifelong learning is expressed more often. Lifelong learning has three basic elements. These are; Continuity; educational process starts in the first year of life and continues until death. Future of education and changes of personalities of individuals have been shaped by education. Creativity; is that individual realizes their potential to adapt to changes. Learning: people learn on their own by asking questions to themselves. Schools must take responsibility to give life-long learning skills, values and attitudes to individiuals (Uzunboylu ve Hürsen, 2011; Erdamar, 2011).

Scientific and technological developments, communication facilities, increasing diversification of the educational environment is effective for the growing interest in lifelong learning. Today, with globalization, the speed of business conditions change and people need to learn more. Therefore, individuals who have completed formal training and then continue education (Erdamar, 2011). Individuals are exposed to various physical, psychological and sociological factors during their personal development. In the social context, lifelong learning aims at gathering a group of individuals to share information for a specific purpose. In the professional context, lifelong learning aims at developing individuals' functional knowledge to help them perform better in their profession (Gunuc, Odabasi \& Kuzu, 2014).

Several studies have explored the quality of life and lifelong learning tendencies of students nevertheless they have contradictory findings. For instance, Sarı (2012) analyzed quality of school life, empathetic perception of classroom atmosphere and level of dependence to friends in high school students. Sarı's (2012) findings revealed that students' life quality and empathetic perception of classroom atmosphere don't differ significantly according to their gender and socio-economic level of school. Furthermore, empathetic perception of classroom atmosphere and dependence to friends dimensions of students predict quality of school life significantly. Sarı, Ötünç and Erceylan (2007) applied a descriptive study and aimed to analyse the high school students' perceptions of school life quality. According to their findings, there is no significant difference between male and female students' perceptions about quality of school life, high socio- economic level schools have higher quality of school life points. Bilgiç and Sarı (2010) analysed perceptions on quality of school life and empathetic perception of classroom atmosphere of primary school students. According to their findings, there is a significant relationship between students' perceptions about quality of school life and empathetic perception of classroom atmosphere. Whereas their study reveals that there is no difference between students' perceptions about quality of school life and empathetic perception of classroom atmosphere according to gender and the points differ according to the level of classroom. Bökeoğlu and Yılmaz (2007) searched for the differences between students' perceptions about quality of faculty life according to the variables of gender, age, faculties, being a member of any student group. It has been seen that the differences between points of quality of faculty life are significant according to faculties, gender and age. Özdemir (2012) analysed the university students' perceptions about quality of school life according to their gender and faculty departments. Their research showed that participants' perceptions about quality of school life differed significantly according to their gender and faculty departments. İzci and Koç (2012) examined the opinions of teacher candidates about lifelong learning. Their findings revealed that the opinions of teacher candidates about lifelong learning differed according to the field of study. Karakuş (2013) aimed to investigate competences for lifelong learning of vocational school students. Findings showed that competences for lifelong learning of vocational school students differed according to the field of study and classroom level. Gencel (2013) examined the perceptions of teacher candidates about lifelong learning competences and findings showed that perceptions of teacher candidates about lifelong learning competences differed according to field of study and gender. Diker, Coşkun and Demirel (2012) examined university students' lifelong learning tendencies and their findings showed that university students about lifelong learning tendencies differed according to their university, gender and classroom level.

The research problems depending on the purpose of this study were searched as whether the opinions of university students about quality of faculty life and their lifelong learning tendencies differ according to their gender, classroom and field of study and whether the opinions of university students about quality of faculty life predict their opinions about their lifelong learning tendencies. 


\section{Methodology}

\subsection{Research Model}

Research design is determined as survey model to examine the difference between the opinions of university students about quality of faculty life and their lifelong learning tendencies according to independent variables. Survey model is used to identify people's attitudes, beliefs, values, habits, thoughts (Mcmillan ve Schumacher, 2001). Besides, the study's design is correlational cause predicting statistics are used to examine whether the opinions of university students about quality of faculty life predicts students' opinions about their lifelong learning tendencies. Correlational studies aim to reveal correlational relationships between variables using correlational statistics (Balc1, 2011).

\subsection{Population and Sample}

The accessible population of the study consists of the university students at Ege University, Faculty of Education in the 2013-2014 academic year. The sample of the study is determined by convenience sampling method and th research was conducted with 375 university students. This method can be applied when sample units are selected from easily accessible due to the existing limitations of the money, time and workforce (Büyüköztürk, Kılıç Çakmak, Akgün, Karadeniz ve Demirel, 2011).

The frequencies are given according to the participants' gender, classroom level and field of the study (Table 1).

Table 1. Demographic informations of university students participating in research

\begin{tabular}{llll}
\hline Variable & Groups & $\mathrm{n}$ & $\%$ \\
\hline Gender & Female & 244 & 65.1 \\
& Male & 131 & 34.9 \\
Classroom level & Sum & 375 & 100.0 \\
& 1 & 167 & 44.5 \\
& 2 & 40 & 10.7 \\
& 3 & 82 & 21.9 \\
Field of study & 4 & 86 & 22.9 \\
& Sum & 375 & 100.0 \\
& Computer And Instructional Technology & 67 & 17.9 \\
& Educational Sciences & 92 & 24.5 \\
& Elementary Education & 201 & 53.6 \\
& Fine Arts Education & 15 & 4.0 \\
& Total & 375 & 100.0 \\
\hline
\end{tabular}

\subsection{Instruments}

\subsubsection{Quality of Faculty Life Scale}

Quality of School Life Scale developed by Epstein and McPartland (1976) and Turkish adaptation of this scale for faculties was made by Yilmaz (2002). Result of the exploratory factor analysis was applied to examine the factor structure of the scale, it was seen that tool had the structure of three dimensions consisting of 40 items. The first factor of the scale named "Satisfaction with Class Environment and Students' Relations" included 10 items. The second factor of the scale named "Satisfaction with Instructors" included 15 items. The third factor of the scale named "Satisfaction with Faculty" included 15 items. In the analysis, the overall Cronbach alpha reliability coefficient of Quality of Faculty Life Scale was calculated and the coefficient was found 0.87. A valid and reliable Likert type scale was adapted to determine the views of university students about the quality of faculty life. Cronbach alpha reliability coefficients calculated to determine reliability of the tool ranged from 0.67 to 0.83 for the dimensions. The scale is answered as follows: 1- I disagree, 2- Undecided, 3- I agree.

\subsubsection{Lifelong Learning Tendency Scale}

Lifelong Learning Tendency Scale developed by Coşkun (2009). Result of the exploratory factor analysis 
applied to examine the factor structure of the scale, it was seen that the tool had a structure of four dimensions consisting of 27 items. The first factor of the scale named "Motivation" included 6 items. The second factor of the scale named "Perseverance" included 6 items. The third factor of the scale named "Lack of learning regulation" included 6 items. The last and fourth factor of the scale named "Lack of curiosity" included 9 items. Responses given items are rated as "very much fits", "partially fits", "very little fits", "does does not fit very little", " does not fit partially", "does not fit at all,". Cronbach alpha reliability coefficient of Lifelong Learning Tendency Scale was calculated and the coefficient was found 0.89 .

\subsection{Analyses}

SPSS 17.00 program is used in the analysis of the data. Single Factor MANOVA is used to examine the difference between the opinions of university students about quality of faculty life and their lifelong learning tendencies according to independent variables. Simple Linear Regression is used to examine whether the opinions of university students about quality of campus life predicts students' opinions about their lifelong learning tendencies and 0.05 level of significance was taken for the interpretation of the results.

\section{Results}

Data obtained from quality of faculty life and lifelong learning tendencies scales were analyzed. Findings are as follows:

Table 2. Single factor manova results of quality of faculty life and lifelong learning tendency according to gender

\begin{tabular}{lllllll}
\hline $\begin{array}{l}\text { Independent } \\
\text { variable }\end{array}$ & $\lambda$ & $\mathrm{F}$ & Hypothesis df & Error df & $\mathrm{p}$ & Eta Square \\
\hline Gender & .01 & 18166.41 & 2.00 & 371.00 & .00 & .99 \\
\hline
\end{tabular}

The opinions of university students about quality of faculty life and lifelong learning tendencies differ according to gender $(\lambda=.01, \mathrm{~F}(2-371)=18166.41, \mathrm{p} \leq .05)$ significantly (Table 2$)$. Eta square value indicating the magnitude of this significant difference was calculated as .99. Accordingly, it can be said that gender has a significant effect on the opinions of university students about quality of faculty life and lifelong learning tendencies. Male students have lower quality of faculty life points than female students $(\bar{X} \mathrm{~m}=78.63$ ve $\bar{X} \mathrm{f}=$ 86.30). In the same manner, male students have higher lifelong learning tendency points than female students $(\bar{X} \mathrm{~m}=98.38, \bar{X} \mathrm{f}=92.52)$.

Table 3. Single factor manova results of quality of faculty life and lifelong learning tendency according to classroom level

\begin{tabular}{lllllll}
\hline $\begin{array}{l}\text { Independent } \\
\text { variable }\end{array}$ & $\lambda$ & $\mathrm{F}$ & Hypothesis df & Error df & $\mathrm{p}$ & Eta Square \\
\hline Classroom level & .99 & 17345.95 & 2.00 & 369.00 & .00 & .99 \\
\hline
\end{tabular}

The opinions of university students about quality of faculty life and lifelong learning tendencies differ according to classroom level $(\lambda=.99, \mathrm{~F}(2-369)=17345.95, \mathrm{p} \leq .05)$ significantly (Table 3$)$. Eta square value indicating the magnitude of this significant difference was calculated as .99. Accordingly, it can be said that classroom level has a significant effect on the opinions of university students about quality of faculty life and lifelong learning tendency. Following this process, post hoc analysis techniques was used. To decide which post hoc technique will be used, the variance of the distribution of the groups tested with Levene's test. It was found that the variances are homogeneous $\left(\mathrm{F}_{\mathrm{qfl}}=2.27, \mathrm{~F}_{\mathrm{llt}}=3.68, \mathrm{p}>05\right)$. So Scheffe technique is preferred. Scheffe test is preferred because the test is sensitive to alpha-type errors. Scheffe, multiple comparison analysis results are presented below: 
Table 4. Scheffe post hoc test results for classroom level variable

\begin{tabular}{|c|c|c|c|c|c|}
\hline Dependent variable & (I) Classroom level & (J) Classroom level & Mean Difference & Std. Error & Sig. \\
\hline \multirow[t]{12}{*}{ Lifelong Learning Tendency } & \multirow[t]{3}{*}{1} & 2 & -6.28 & 2.31 & .06 \\
\hline & & 3 & -.41 & 1.77 & 1.00 \\
\hline & & 4 & 3.63 & 1.75 & .23 \\
\hline & \multirow[t]{3}{*}{2} & 1 & 6.28 & 2.31 & .06 \\
\hline & & 3 & 5.88 & 2.53 & .15 \\
\hline & & 4 & 9.91 & 2.52 & .00 \\
\hline & \multirow[t]{3}{*}{3} & 1 & .41 & 1.77 & 1.00 \\
\hline & & 2 & -5.88 & 2.53 & .15 \\
\hline & & 4 & 4.04 & 2.03 & .27 \\
\hline & \multirow[t]{3}{*}{4} & 1 & -3.63 & 1.75 & .23 \\
\hline & & 2 & -9.91 & 2.52 & .00 \\
\hline & & 3 & -4.04 & 2.03 & .27 \\
\hline \multirow[t]{12}{*}{ Quality of Faculty Life } & \multirow[t]{3}{*}{1} & 2 & 4.52 & 2.08 & .20 \\
\hline & & 3 & 14.38 & 1.59 & .00 \\
\hline & & 4 & .95 & 1.57 & .95 \\
\hline & \multirow[t]{3}{*}{2} & 1 & -4.52 & 2.08 & .20 \\
\hline & & 3 & 9.86 & 2.28 & .00 \\
\hline & & 4 & -3.57 & 2.26 & .48 \\
\hline & \multirow[t]{3}{*}{3} & 1 & -14.38 & 1.59 & .00 \\
\hline & & 2 & -9.86 & 2.28 & .00 \\
\hline & & 4 & -13.43 & 1.83 & .00 \\
\hline & \multirow[t]{3}{*}{4} & 1 & -.95 & 1.57 & .95 \\
\hline & & 2 & 3.57 & 2.26 & .48 \\
\hline & & 3 & 13.43 & 1.83 & .00 \\
\hline
\end{tabular}

According to classroom level variable; opinions of university students about quality of faculty life and lifelong learning tendencies differ and to determine which groups have differences, Scheffe test was used and results indicate that there are differences between classroom levels 2-4. ( $\mathrm{p} \leq .05)$ (Table 4). This case shows: Second grade students have higher lifelong learning tendency points than fourth grade students $\left(\bar{X}_{2}=100.92, \bar{X}_{4}=\right.$ 91.01). In addition, there is difference between lifelong learning tendency points of third grade and the other students $(\mathrm{p} \leq .05)$. Third grade students have lower quality of faculty life points than the other students $\left(\bar{X}_{3}=73\right.$, $09, \bar{X}_{1}=87.47, \bar{X}_{2}=82.95, \bar{X}_{4}=86.52$ ).

Table 5. Single factor manova results of quality of faculty life and lifelong learning tendency according to field of study

\begin{tabular}{lllllll}
\hline $\begin{array}{l}\text { Independent } \\
\text { variable }\end{array}$ & $\lambda$ & $\mathrm{F}$ & Hypothesis df & Error df & $\mathrm{p}$ & Eta Square \\
\hline Field Of Study & .02 & 8926.69 & 2.00 & 369.00 & .00 & .98 \\
\hline
\end{tabular}

The opinions of university students about quality of faculty life and lifelong learning tendencies differ according to field of study $(\lambda=.01, F(2-369)=8926,68, p \leq .05)$ (Table 5). Eta square value indicating the magnitude of this significant difference was calculated as .98 . Accordingly, it can be said that field of study has a significant effect on the opinions of university students about quality of faculty life and lifelong learning tendency. Following this 
process, post hoc analysis techniques was used. To decide which post hoc technique is used, variance of the distribution of the groups tested with Levene's test. It was found that the variances are homogeneous $\left(\mathrm{F}_{\mathrm{qfl}}=1.97\right.$ $\mathrm{F}_{1 \mathrm{lt}}=2.20 \mathrm{p}>05$ ). So Scheffe technique is preferred. Scheffe, multiple comparison analysis results are presented below:

Table 6. Scheffe post hoc test results for field of study variable

\begin{tabular}{|c|c|c|c|c|c|c|}
\hline $\begin{array}{l}\text { Dependent } \\
\text { variable }\end{array}$ & (I) field & (J) field & & $\begin{array}{l}\text { Mean } \\
\text { Difference }\end{array}$ & $\begin{array}{l}\text { Std. } \\
\text { Error }\end{array}$ & Sig. \\
\hline \multirow{12}{*}{$\begin{array}{l}\text { Lifelong } \\
\text { Learning } \\
\text { Tendency }\end{array}$} & \multirow{3}{*}{$\begin{array}{l}\text { Computer And } \\
\text { Instructional } \\
\text { Technology }\end{array}$} & \multicolumn{2}{|l|}{ Educational Sciences } & 6.13 & 2.12 & .04 \\
\hline & & \multicolumn{2}{|l|}{ Elementary Education } & 4.43 & 1.86 & .13 \\
\hline & & \multicolumn{2}{|l|}{ Fine Arts Education } & 9.85 & 3.77 & .08 \\
\hline & \multirow[t]{3}{*}{$\begin{array}{l}\text { Educational } \\
\text { Sciences }\end{array}$} & $\begin{array}{l}\text { Computer And } \\
\text { Technology }\end{array}$ & Instructional & -6.13 & 2.12 & .04 \\
\hline & & Elementary Education & & -1.70 & 1.66 & .79 \\
\hline & & Fine Arts Education & & 3.72 & 3.68 & .80 \\
\hline & \multirow[t]{3}{*}{$\begin{array}{l}\text { Elementary } \\
\text { Education }\end{array}$} & $\begin{array}{l}\text { Computer And } \\
\text { Technology }\end{array}$ & Instructional & -4.43 & 1.86 & .13 \\
\hline & & Educational Sciences & & 1.70 & 1.66 & .79 \\
\hline & & Fine Arts Education & & 5.42 & 3.53 & .50 \\
\hline & \multirow[t]{3}{*}{$\begin{array}{l}\text { Fine } \\
\text { Education }\end{array}$} & $\begin{array}{l}\text { Computer And } \\
\text { Technology }\end{array}$ & Instructional & -9.85 & 3.77 & .08 \\
\hline & & Educational Sciences & & -3.72 & 3.68 & .80 \\
\hline & & Elementary Education & & -5.42 & 3.53 & .50 \\
\hline \multirow{12}{*}{$\begin{array}{l}\text { Quality } \\
\text { Faculty Life }\end{array}$} & \multirow{3}{*}{$\begin{array}{l}\text { Computer And } \\
\text { Instructional } \\
\text { Technology }\end{array}$} & Educational Sciences & & -9.97 & 2.02 & .00 \\
\hline & & Elementary Education & & -2.98 & 1.78 & .42 \\
\hline & & Fine Arts Education & & -11.28 & 3.60 & .02 \\
\hline & \multirow[t]{3}{*}{$\begin{array}{l}\text { Educational } \\
\text { Sciences }\end{array}$} & $\begin{array}{l}\text { Computer And } \\
\text { Technology }\end{array}$ & Instructional & 9.97 & 2.02 & .00 \\
\hline & & Elementary Education & & 6.99 & 1.59 & .00 \\
\hline & & Fine Arts Education & & -1.31 & 3.50 & .99 \\
\hline & \multirow[t]{3}{*}{$\begin{array}{l}\text { Elementary } \\
\text { Education }\end{array}$} & $\begin{array}{l}\text { Computer And } \\
\text { Technology }\end{array}$ & Instructional & 2.98 & 1.78 & .42 \\
\hline & & Educational Sciences & & -6.99 & 1.59 & .00 \\
\hline & & Fine Arts Education & & -8.31 & 3.37 & .11 \\
\hline & \multirow[t]{3}{*}{$\begin{array}{l}\text { Fine } \\
\text { Education }\end{array}$} & $\begin{array}{l}\text { Computer And } \\
\text { Technology }\end{array}$ & Instructional & 11.28 & 3.60 & .02 \\
\hline & & Educational Sciences & & 1.31 & 3.50 & .99 \\
\hline & & Elementary Education & & 8.31 & 3.37 & .11 \\
\hline
\end{tabular}

According to field of study variable, opinions of university students about quality of faculty life and lifelong learning tendency differ and to determine which groups have differences so Scheffe test is implemented and results reveal that differences between computer and instructional technology students and educational sciences students $(\mathrm{p} \leq .05)$. Educational sciences students have lower lifelong learning tendency points computer and instructional technology students $\left(\bar{X}_{\text {cit }}=98.85, \bar{X}_{\text {es }}=92.72\right)$ (Table 6). There are differences between points of computer and instructional technology students and points of educational sciences students and fine arts students. Computer and instructional technology students have lower quality of faculty life points than the others 
$\left(\bar{X}_{\text {cit }}=79.12, \quad \bar{X}_{\mathrm{es}}=89.09, \bar{X}_{\mathrm{fa}}=90.40\right)$. And there are differences between points of educational sciences students and elementary education students. Educational sciences students have higher quality of faculty life points than elementary education students $\left(\bar{X}_{\mathrm{es}}=89.09, \bar{X}_{\mathrm{ee}}=82.10\right)$.

Table 7. Simple linear regression analysis results

\begin{tabular}{|c|c|c|c|c|c|}
\hline Variables & B & Std. Error & $\beta$ & $\mathrm{t}$ & $\mathrm{p}$ \\
\hline Constant & 107.62 & 4.42 & & 24.33 & .00 \\
\hline $\begin{array}{l}\text { Quality of } \\
\text { Faculty Life }\end{array}$ & -.15 & .05 & -.15 & -2.99 & .00 \\
\hline \multicolumn{6}{|c|}{$\mathrm{R}=.15, \mathrm{R}^{2}=.02$, Adjusted $\mathrm{R}^{2}=.02 \mathrm{~F}(1-373)=8.91, \mathrm{p}=.00$} \\
\hline
\end{tabular}

Examining the results of t-test, $\left[\mathrm{R}=.15, \mathrm{R}^{2}=.02\right.$, Adjusted $\left.\mathrm{R}^{2}=.02 \mathrm{~F}(1-373)=8.91, \mathrm{p}=.00\right]$ the opinions of university students about quality of faculty life is a significant predictor of their opinions about life long learning tendencies $(\mathrm{p} \leq .05)$. Students' perception of the quality of faculty life explains $2 \%$ of the total variance of lifelong learning tendency (Table 7).

\section{Discussion and Conclusion}

In this research the results revealed that the opinions of university students about quality of faculty life and lifelong learning tendencies differed significantly according to their gender. Male students have lower quality of faculty life points than female students. In the same manner, male students have higher lifelong learning tendency points than female students. Similarly, Bökeoğlu and Yılmaz (2007) found students' perception about quality of faculty life differ according to faculties, gender and age. Gencel (2013) found that perceptions of teacher candidates about lifelong learning competences differ according to gender. Diker, Coşkun ve Demirel (2012) found that university students' lifelong learning tendencies differ according to their gender. On the contrary, Bilgiç and Sarı (2010) found there was no difference between students' perceptions about quality of school life according to their gender.

Furthermore the results of this study indicated that the opinions of university students about quality of faculty life and lifelong learning tendencies differed significantly according to their classroom level. Second grade students have higher lifelong learning tendency points than fourth grade students. Third grade students have lower quality of faculty life points than the other students. Similarly, Sarı, Ötünç and Erceylan (2007) found that opinions of participants about quality of school life differed significantly according to class and socio- economic level. Bilgiç and Sarı (2010) found that there was a significant difference between students' perceptions about quality of school life according to classroom level. Karakuş (2013) found that competences for lifelong learning of vocational school students differed according to classroom level. Diker Coşkun and Demirel (2012) found university students about lifelong learning tendencies differed classroom level

The results of this study revealed that the quality of faculty life of university students differed significantly according to the field of study. Educational sciences students have lower lifelong learning tendency than computer and instructional technology students. Computer and instructional technology students have the lowest quality of faculty life of all. Educational sciences students have higher quality of faculty life than elementary education students. Similarly, Özdemir (2012) analysed the university students' perception about quality of school life based on the variables of gender and faculty and participants' perceptions about quality of school life and found that they differed significantly according to gender and faculty departments. İzci and Koç (2012) found that the opinions of teacher candidates about lifelong learning differed according to the field of study. Karakuş (2013) found that competences for lifelong learning of vocational school students differed according to field of study. Gencel (2013) also found that perceptions of teacher candidates about lifelong learning competences differed according to field of study.

Additionaly, the opinions of university students about quality of faculty life is a significant predictor of their opinions about life long learning tendency. So by the findings, university students' quality of faculty life and their lifelong learning tendencies differ according to gender, classroom level and field of study. Students' opinions to fulfill their goals are seen vital as being one of the most important factor within the context of university management. It is important that to research and find out the quality of faculty life and life learning 
tendecies of university students to increase the level of quality of faculty life and generating education policies according to their results. Therefore, analysing the opinions of university students on quality of faculty life and lifelong learning tendencies is expected to use as a leverage to manage the faculty effectively and provide important benefits to researchers and implementors. Faculty management can develop physical infra structure and human resources management strategies to increase the quality of faculty life and their lifelong learning tendencies. Besides, lifelong learning can be effected by other variables and they may be investigated.

\section{References}

Ayhan, S. (2005). Lifelong Learning. Ankara: Pegem A Publications.

Balc1, A. (2011). Social Science Research Methods, Techniques and Principles. Ankara: Pegem Akademi.

Bilgiç, S., \& Sarı, M. (2010). Perceived quality of school life and empathic classroom atmosphere among elementary school students. Educational Sciences and Practice, 9(17), 1-19.

Büyüköztürk, Ş., Kılıç, E., Akgün, Ö., Karadeniz,Ş., \& Demirel, F. (2011). Scientific Research Methods. Ankara: Pegem Akademi.

Coşkun Diker, Y. (2009). Examining lifelong learning tendencies of university students according to some variables. Hacettepe University, Social Science Institute, Educational Science Department. Unpublished doctoral dissertation. Ankara.

Çokluk Bökeoğlu, Ö., \& Yılmaz, K. (2007). Analysis of University Students' Views about the Quality of Faculty Life Using Various Variables, Ankara University, Journal of Faculty of Educational Sciences, 40(2), 179-204.

Diker Coşkun, Y., \& Demirel, M. (2012). Lifelong learning tendencies of university students. H. U. Journal of Education, 42, 108-120.

Epstein, J. L., \& McPartland, J. M. (1976). The concept and measurement of the quality of school life. American Educational Research Journal, 13(1), 15-30. http://dx.doi.org/10.3102/00028312013001015

Erdamar, G. (2011). Lifelong Learning. Ankara: Pegem Akademi.

Gencel, İ. (2013). Prospective Teachers' Perceptions towards Lifelong Learning Competencies. Education and Science, 38(170), 237-252.

Gunuc, S, Odabasi, H. F., \& Kuzu, A. (2014). Developing an Effective Lifelong Learning Scale (ELLS): Study of Validity \& Reliability. Education and Science, 39(171), 244-258.

İzci, E., \& Koç, S. (2012). The evaluation of the teacher candidates' views on the life long learning. Adryaman University Social Sciences Institute Journal, 5(9), 101-114.

Karakuş, C. (2013). Lifelong learning competences of vocational school students. Journal of Research in Education and Teaching, 2(3), 26-35.

Leonard, C. A. R. (2002). Quality of life and attendance in primary schools. Unpublished Doctoral Dissertation. Newcastle: University of Newcastle.

Mcmillan, J. H., \& Schumacher, S. (2001). Research in education. A conceptual introduction (5th ed.). New York: Addison Wesley Longman Inc.

Özdemir, M. (2012). Examination of university students' perceptions on the quality of school life based on gender and faculty. Educational Administration: Theory and Practice, 18(2), 225-242.

Sar1, M. (2012). Effects of empathic classroom atmosphere and peer attachment on school life quality among high school students. Educational Administration: Theory and Practice, 18(1), 95-119.

Sarı, M., Ötünç, E., \& Erceylan, H. (2007). Quality of life in high schools: The case of Adana Province. Educational Administration: Theory and Practice, 50, 297-320.

Schmidt, L. J. (1992). Relationship between pupil control ideology and quality of school life. Journal of Invitational and Psychological Measurement, 45, 889-896.

Schmidt, L. J., \& Lunenburg, F. C. (1989). Pupil control ideology, pupil control behavior and the quality of school life. Journal of Research and Development in Education, 22, 36-44.

Schofield, N. J., \& Bourke, S. F. (1997). Absenteeism, student quality of school life and teacher stress in primary school. Paper presented at the EARLI Conference. Athens.

Şişman, M. (2012). Introduction to educational sciences. Ankara: Pegem Akademi. 
Uzunboylu, H., \& Hürsen, Ç. (2011). Principles and methods of teaching. Ankara: Pegem Akademi.

Waugh, R., \& Hyde, N. (1993). Student perceptions of school. Paper presented at the Annual Conference of the Australian Association for Research in Education. Fremantle, November.

Wilson, A. (1980). Landmarks in the literature: How powerful is schooling. New York University EducationQuarterly, 11, 8-31.

Yılmaz, K., \& Çokluk-Bökeoğlu, Ö. (2006). The quality of faculty life scale: A study on validity and reliability. Gazi University, Turkish Educational Science Journal, 4(2), 201-210.

\section{Copyrights}

Copyright for this article is retained by the author(s), with first publication rights granted to the journal.

This is an open-access article distributed under the terms and conditions of the Creative Commons Attribution license (http://creativecommons.org/licenses/by/3.0/). 